\title{
Two Distinct Receptors Account for Recognition of Maleyl-Albumin in Human Monocytes during Differentiation In Vitro
}

\author{
Margaret E. Haberland, Ronald R. Rasmussen, Christopher L. Olch, and Alan M. Fogelman \\ Division of Cardiology, Department of Medicine, School of Medicine, University of California, Los Angeles, California 90024
}

\begin{abstract}
A comparison of the receptor-mediated interaction of malondialdehyde-low density lipoprotein and maleyl-albumin has been examined in human monocytes during differentiation in vitro. The recognition of both ligands by the scavenger receptor of these cells has been confirmed. We now report that human monocytes express a second cellular surface receptor for maleylalbumin that is distinct from the scavenger receptor. The activity of the maleyl-albumin receptor, determined by both binding and lysosomal hydrolytic assays, substantially exceeds that of the scavenger receptor in freshly isolated monocytes. A dramatic and rapid decline in the activity of the maleyl-albumin receptor occurs within 72 to $96 \mathrm{~h}$ during differentiation in vitro. At day 7, while only 5-10\% of the original activity of the maleyl-albumin receptor remains, it is similar to that of the maximally expressed scavenger receptor. Both the binding and hydrolysis of ligand mediated by the maleyl-albumin receptor are specifically inhibited by $\alpha$-casein and alkaline-treated albumin; neither of these proteins is recognized by the scavenger receptor.

The occurrence of the exceptionally active maleyl-albumin receptor on freshly isolated human monocytes suggests that it participates in processes necessary to the function of the cells that diminish in importance after differentiation of the monocytes into macrophages in vitro. Furthermore, while maleyl-albumin is a useful adjunct to studies of cellular events mediated by the scavenger receptor, the presence of a second receptor for maleylalbumin must be taken into account as a potential contributing and complicating event.
\end{abstract}

\section{Introduction}

Macrophages play a pivotal role in the process of disposal of foreign pathogens and toxins, in the immune response to foreign antigens, and in the repair of injury. More recently it has become apparent that certain of these functions of macrophages may likewise account for their participation in the development of the atherosclerotic lesions (1-10). Studies conducted in 1979 by Gerrity et al. (3) and continued by Gerrity $(4,5)$ as well as investigations in 1984 by Faggiotto et al. (8) in animals with dietinduced atherosclerosis have convincingly demonstrated that the early events of atherogenesis include the recruitment of blood monocytes to lesion-prone areas in the arterial wall, the migration of monocytes to subendothelial locations within the intima, and the conversion of monocytes to lipid-laden macrophages characteristic of the foam cells of the atherosclerotic lesion.

Address reprint requests to Dr. Haberland. Ensign Olch's present address is U.S. Uniformed Health Services School of Medicine, Bethesda, MD 20205.

Received for publication 1 October 1985.

J. Clin. Invest.

(C) The American Society for Clinical Investigation, Inc.

0021-9738/86/03/0681/09 \$1.00

Volume 77, March 1986, 681-689
The potential mechanisms accounting for the massive deposition of cholesteryl esters in macrophages have been actively studied by a number of investigators and have been considered to be initiated by the receptor-mediated uptake of several different classes of lipoproteins and lipoprotein complexes (reviewed in reference 11). The scavenger receptor, first described in murine peritoneal macrophages by Goldstein et al. (12), has been of interest in this regard for several reasons: the internalization and hydrolysis of lipoprotein mediated by the scavenger receptor produce rapid intracellular accumulation of cholesteryl esters derived from hydrolysis and reesterification of lipoprotein-derived cholesterol; the receptor is selectively present on macrophages and endothelial cells from a number of species; and alteration of low density lipoproteins (LDL), either by chemical or cellular modification, is a prerequisite to inducing recognition by the scavenger receptor (11). The scavenger receptor, as isolated from murine $\mathrm{P}_{388 \mathrm{D}_{1}}$ macrophages, has recently been identified as a glycoprotein of $260,000 \mathrm{D}$ by Via et al. (13). In addition to facilitating the internalization of modified LDL, receptor engagement by maleyl-albumin or fucoidin, previously identified as competitive ligands for the scavenger receptor $(12,14)$, triggers the release of neutral proteases, plasminogen activator, and cytolytic factors from peritoneal macrophages obtained from bacillus Calmett-Guerin-primed mice (15).

The structures of the binding determinants promoting the recognition of ligands by the scavenger receptor have yet to be elucidated. We have provided evidence that alteration in the conformation of the protein components accounts for the recognition of malondialdehyde-LDL, acetyl-LDL, and succinyl$\operatorname{LDL}(16,17)$, as well as of maleyl-albumin (18) by the scavenger receptor. During the course of these investigations, we noted that, although maleyl-albumin competed on an equimolar basis with malondialdehyde-LDL for recognition by the scavenger receptor (18), the rate of hydrolysis of maleyl-albumin by human monocyte macrophages exceeded that of malondialdehyde-LDL. A direct comparison of the interaction of these ligands with human monocytes maintained in culture was then initiated to determine if maleyl-albumin, like malondialdehyde-LDL $(12,19)$, was indeed a ligand selectively recognized by the scavenger receptor. The studies reported here present evidence that, in addition to the scavenger receptor, there is a second, distinct receptor that participates in the binding, internalization, and lysosomal hydrolysis of maleyl-albumin in the human cells. The activity of the second receptor for maleyl-albumin substantially exceeds that of the scavenger receptor in freshly isolated human blood monocytes, and rapidly declines to approach the activity of the scavenger receptor in macrophages derived in culture from monocytes.

\section{Methods}

Materials. Sodium [ $\left.{ }^{125} \mathrm{I}\right]$ iodide $(15 \mathrm{mCi} / \mu \mathrm{g} ; 1 \mathrm{Ci}=37 \mathrm{GBq})$ was purchased from Amersham Corp., Arlington Heights, IL. Polyinosinic acid, dextran 
sulfate, spermine, $\alpha$-casein, rabbit and porcine albumin, and $N$-formylmethionyl-leucyl-phenylalanine were obtained from Sigma Chemical Co. (St. Louis, MO); maleic anhydride and acetic anhydride were from Aldrich Chemical Co. (Milwaukee, WI); crystallized bovine plasma albumin (catalogue 2266-01) was from Armour Pharmaceutical Co. (Kankakee, IL); human serum albumin (catalogue 10881) was from United States Biochemical Corp. (Cleveland, OH); fucoidin was from ICN Biochemicals (Cleveland, $\mathrm{OH}$ ); and lysinoalanine was from Miles Scientific (Naperville, IL). All other supplies and reagents were obtained from sources previously reported in Fogelman et al. $(19,20)$.

Subjects. Normal subjects were recruited from the staff and student body at the University of California, Los Angeles. No one received drugs that might have affected serum cholesterol levels or lipid metabolism. All had normal hematocrits, leukocyte and differential counts, serum cholesterol, and triglycerides. Informed consent was obtained in writing from each person.

Separation of cells. $500 \mathrm{ml}$ of blood was taken after an overnight fast, and the monocytes were separated from $300 \mathrm{ml}$ of venous blood by counterflow centrifugation (method BB in Fogelman et al. [19]).

Cell culture. Cells were suspended in $30 \%$ autologous serum in Dulbecco's modified Eagle's medium supplemented with $24 \mathrm{mM} \mathrm{NaHCO}{ }_{3}$, $10 \mathrm{mM}$ 4-(2-hydroxyethyl) 1-piperazineethanesulfonic acid, $8 \mu \mathrm{g}$ insulin/ $\mathrm{ml}$, and $0.25 \mu \mathrm{g}$ of fungizone/ $\mathrm{ml}$ (called medium B to be consistent with our previous publications $[19,20])$. Samples $(0.5 \mathrm{ml})$ of the cell suspension containing $1.0 \times 10^{6}$ cells for studies to be conducted within $18 \mathrm{~h}$ after isolation of the monocytes, or $0.5-\mathrm{ml}$ samples of the cell suspension containing $0.5 \times 10^{6}$ cells for studies to be conducted with monocytes maintained $>24 \mathrm{~h}$ in culture were transferred to $2.0-\mathrm{cm}^{2}$ polystyrene wells (Falcon 3047) and incubated at $37^{\circ} \mathrm{C}$ in a humidified, $5 \% \mathrm{CO}_{2}$ incubator. The medium was aspirated and replaced with fresh medium of the same composition twice weekly.

Classification and viability of the cells. The cells were classified and their viability was determined as described (21). Because of the media changes and the washes before beginning each experiment, the cells were 99\% monocyte macrophages before the radioactive lipoproteins were added. More than $95 \%$ of the cells were viable at the end of the incubation.

Preparation of sera. Autologous serum was prepared from $200 \mathrm{ml}$ of blood as described in Fogelman et al. (19).

Preparation and chemical modification of proteins. Human LDL $(d 1.019-1.063 \mathrm{~g} / \mathrm{ml})$ was isolated from the serum of individual healthy human subjects by ultracentrifugation (22). $\beta$-Very low density lipoproteins isolated from plasma of cholesterol-fed rabbits were kindly provided by Dr. Van Lenten of this laboratory. LDL and human albumin were modified by malondialdehyde as described (16) and dialyzed against $0.01 \mathrm{M}$ sodium phosphate, $\mathrm{pH} 7.4$, and $0.15 \mathrm{M}$ sodium chloride, $0.01 \%$ EDTA (buffer A).

The half-cystyl derivative of crystallized bovine plasma albumin $(3 \mathrm{~g})$ was prepared by the method of King and Spencer (23) and dialyzed for $36 \mathrm{~h}$ at $4^{\circ} \mathrm{C}$ against $0.2 \mathrm{M}$ sodium phosphate ( $\mathrm{pH} 9.0$ ). Maleylation of half-cystyl bovine plasma albumin was conducted according to the method of Butler and Hartley (24), using recrystallized maleic anhydride. The maleylated protein was dialyzed for $48 \mathrm{~h}$ at $4^{\circ} \mathrm{C}$ against $0.01 \mathrm{M}$ ammonium bicarbonate, lyophilized, and stored at $-10^{\circ} \mathrm{C}$. Desired samples were reconstituted in buffer $\mathrm{A}$ and dialyzed for $16 \mathrm{~h}$ at $4^{\circ} \mathrm{C}$ against buffer $A$ before use. Modification of half-cystyl human albumin by acetic anhydride was conducted by the method of Goldstein et al. (12) or by reductive methylation as described by Weisgraber et al. (25). Alkaline-treated human albumin was prepared according to the method of Wilkinson and Allan (26).

Porcine albumin was purified by adsorption to Blue Sepharose CL6B (Pharmacia Fine Chemicals, Piscataway, NJ) in $0.05 \mathrm{M}$ potassium chloride, $0.05 \mathrm{M}$ Tris- $\mathrm{HCl}, \mathrm{pH} 7.2$, and elution with $0.5 \mathrm{M}$ potassium chloride, $0.05 \mathrm{M}$ Tris- $\mathrm{HCl}, \mathrm{pH}$ 7.2. The half-cystyl derivatives of both porcine and rabbit albumins were prepared and maleylation performed as described for the bovine protein.

Labeling of LDL and maleyl-albumin with ${ }^{125}$ I was performed by the method of McFarlane (27) as modified by Bilheimer et al. (28).
Assays of chemical modification. The malondialdehyde adduct of LDL was quantitated by colorimetric assay with thiobarbituric acid as reported by Fogelman et al. (29). The extent of lysine modification was determined by the method of Habeeb (30) with trinitrobenzenesulfonic acid as the difference in lysyl residues of modified and unmodified protein preparations. Molar ratios were calculated assuming a total molecular weight of 500,000 for protein of LDL (31), 66,210 for half-cystyl bovine plasma albumin (32), 68,900 for maleyl-albumin (15), and 27,400 for bovine $\alpha$-casein (33). Chemical derivatization of LDL by malondialdehyde typically resulted in modification of $38-48 \%$ of the lysyl residues of the apolipoprotein B polypeptides; maleylation, acetylation, and reductive methylation of albumin resulted in modification of $>94 \%$ of the peptidyl lysines. The concentrations of protein samples used in cellular assay, given in molar terms, were calculated from the molecular weights stated above and the protein concentrations determined by the method of Lowry et al. (34) with bovine plasma albumin as a standard.

Cellular assays. Before initiating studies, cells in culture were washed three times with 1-ml vol of Dulbecco's modified Eagle's medium containing $10 \mathrm{mM}$ 4-(2-hydroxyethyl) 1-piperazineethanesulfonic acid (medium C). Cells to be used in binding studies were chilled for $60 \mathrm{~min}$ at $4^{\circ} \mathrm{C}$ before initiating the binding protocol described in the figure legends. After $3 \mathrm{~h}$ of gentle rotation on a platform $(60 \mathrm{rpm})$, the cells were sequentially washed four times with $1 \mathrm{ml}$ of phosphate-buffered saline containing $0.2 \%$ bovine serum albumin and one time with $1 \mathrm{ml}$ of phosphate-buffered saline; the first wash was allowed to sit $10 \mathrm{~min}$ before proceeding with the remaining washes in rapid succession. Each well then received $0.4 \mathrm{ml}$ of $0.1 \mathrm{~N}$ sodium hydroxide, and after $30 \mathrm{~min}$ at $37^{\circ} \mathrm{C}$ the cellular extract was quantitatively transferred to gamma vials for determination of radioactivity. Wells without cells, prepared by incubation with $30 \%$ autologous serum in medium B for $24 \mathrm{~h}$ at $37^{\circ} \mathrm{C}$, were treated identically to serve as blanks. For studies at $37^{\circ} \mathrm{C}$, radioactive proteins were added in medium $\mathrm{C}$ supplemented with $25 \mathrm{mM} \mathrm{NaHCO}_{3}$ and $2 \mathrm{mg}$ of glucose/ml (medium D) to the cells, and the cells were returned to the incubator for the indicated times. The proteolytic degradation of ${ }^{125}$ I-labeled protein was measured by assaying the amount of ${ }^{125}$ I-labeled trichloroacetic acid-soluble (noniodide) material formed by the cells and excreted into the culture medium as described by Goldstein and Brown (35). Corrections were made for the small amounts $\left(<0.01 \%\right.$ of total radioactivity added) of ${ }^{125}$ I-labeled acid-soluble material that was formed in parallel incubations without cells. To measure the amount of ${ }^{125}$ I-lipoprotein associated with cells, the medium containing the radioactive lipoprotein was removed and replaced with $2 \mathrm{ml}$ of chilled phosphate-buffered saline containing $0.2 \%$ bovine serum albumin. The cells were placed on ice for $10 \mathrm{~min}$, and the washing procedure described for binding studies was employed. Binding analyses of freshly isolated monocytes were conducted at $4^{\circ} \mathrm{C}$ as described by Van Lenten et al. (36). The protein content of cells solubilized by $0.1 \mathrm{M}$ sodium hydroxide was measured by the method of Lowry et al. (34) with bovine plasma albumin as a standard. Statistical analyses were conducted by methods previously cited (19).

\section{Results}

In an earlier investigation we determined the activity of the scavenger receptor of human monocytes cultured in vitro by assaying the rate of hydrolysis of ${ }^{125} \mathrm{I}$-malondialdehyde-MDALDL (MDA-LDL), ${ }^{1}$ and showed that the activity decreased within several hours after adherence of the cells (19). The activity

1. Abbreviations used in this paper: malondialdehyde-, succinyl-, acetyl-, maleyl-, or reductively methylated-protein, protein chemically modified by malondialdehyde, succinic anhydride, acetic anhydride, maleic anhydride, or formaldehyde with borohydride reduction, respectively; maleyl-BPA, maleyl-bovine plasma albumin; MDA-LDL, malondialdehyde-LDL. 
of the scavenger receptor gradually developed as a function of time in culture and was maximally expressed in macrophages derived from monocytes after a week in culture (19). Thus, comparison of the interaction of maleyl-albumin and malondialdehyde-LDL with human monocytes was initiated in the more mature cells to ensure that optimal activity of the scavenger receptor was present. Fig. 1 shows the rates of degradation of both radioiodinated ligands as a function of molar concentration. Both the saturation kinetics and the total rates of degradation differed markedly for ${ }^{125}$ I-MDA-LDL (Fig. $1 \mathrm{~A}$ ) and ${ }^{125}$ I-maleylalbumin (Fig. $1 B$ ). Polyinosinic acid has previously been shown to be an effective and specific inhibitor of ligands recognized by the scavenger receptor of murine peritoneal macrophages (14) and human monocyte macrophages (17). The ability of polyinosinic acid to suppress effectively the degradation of ${ }^{125} \mathrm{I}-\mathrm{MDA}$ LDL is also shown in Fig. $1 \mathrm{~A}$. In contrast, as shown in Fig. 1 $B$, the hydrolysis of ${ }^{125} \mathrm{I}$-maleyl-albumin was only partially inhibited by the addition of polyinosinic acid. The rates of hydrolysis of ${ }^{125} \mathrm{I}-\mathrm{MDA}-\mathrm{LDL}$ and ${ }^{125} \mathrm{I}$-maleyl-albumin that were specifically suppressed by the addition of polyinosinic acid are compared in Fig. $1 \mathrm{C}$. The kinetics for hydrolysis of the two ligands appeared similar, with saturation for malondialdehydeLDL occurring at $\sim 30 \mathrm{nM}(15 \mu \mathrm{g} / \mathrm{ml})$ and for maleyl-albumin at $\sim 100 \mathrm{nM}(7 \mu \mathrm{g} / \mathrm{ml})$.

We have previously determined that maleyl-albumin competes on an equimolar basis with MDA-LDL for uptake and hydrolysis mediated by the scavenger receptor (18). The data of Fig. 1 implied that the converse did not apply. This was supported by cross-competition analyses as shown in Fig. 2. Nonradioactive malondialdehyde-LDL only partially competed with ${ }^{125}$ I-maleylalbumin, whether tested at a concentration near saturation of the scavenger receptor by malondialdehyde-LDL (Fig. $2 B$ ) or at a concentration near saturation of the scavenger receptor by maleyl-albumin (Fig. $2 \mathrm{~A}$ ). Furthermore, the ability of a 40 -fold molar excess of malondialdehyde-LDL to suppress the hydrolysis of ${ }^{125} \mathrm{I}$-maleyl-albumin diminished from 45 to $25 \%$ as the concentration of ${ }^{125}$ I-maleyl-albumin increased. In the same experiments, nonradioactive maleyl-albumin readily suppressed $80 \%$ of the hydrolysis of ${ }^{125} \mathrm{I}$-maleyl-albumin (Fig. 2, $A$ and $B$ ). In both cases, $50 \%$ inhibition of the hydrolysis of ${ }^{125} \mathrm{I}$-maleyl-albumin was produced at the same molar ratio of nonradioactive to radioactive maleyl-albumin.

Additional competition experiments with several other known inhibitors of the uptake of ligand by the scavenger receptor were conducted. As shown in Fig. 3, dextran sulfate and fucoidin readily suppressed $>85 \%$ of the hydrolysis of ${ }^{125}$ I-MDALDL mediated by the scavenger receptor, as previously demonstrated by Goldstein, Brown, and colleagues $(11,12,14)$. Furthermore, the ability of dextran sulfate to compete could be abolished by the addition of spermine (Fig. $3 \mathrm{~A}$ ). Both fucoidin and dextran sulfate were less effective in preventing the hydrolysis of ${ }^{125} \mathrm{I}$-maleyl-albumin. The effect of dextran sulfate upon the hydrolysis of ${ }^{125} \mathrm{I}$-maleyl-albumin could be prevented by the addition of spermine. Competitive experiments conducted with polyinosinic acid produced results similar to those obtained with fucoidin and dextran sulfate (data not shown).

Taken together, these results confirmed that polyinosinic acid, dextran sulfate, fucoidin, and malondialdehyde-LDL each effectively suppressed the uptake and hydrolysis of modified LDL specifically recognized by the scavenger receptor of macrophages (14). However, since the hydrolysis of maleyl-albumin was only
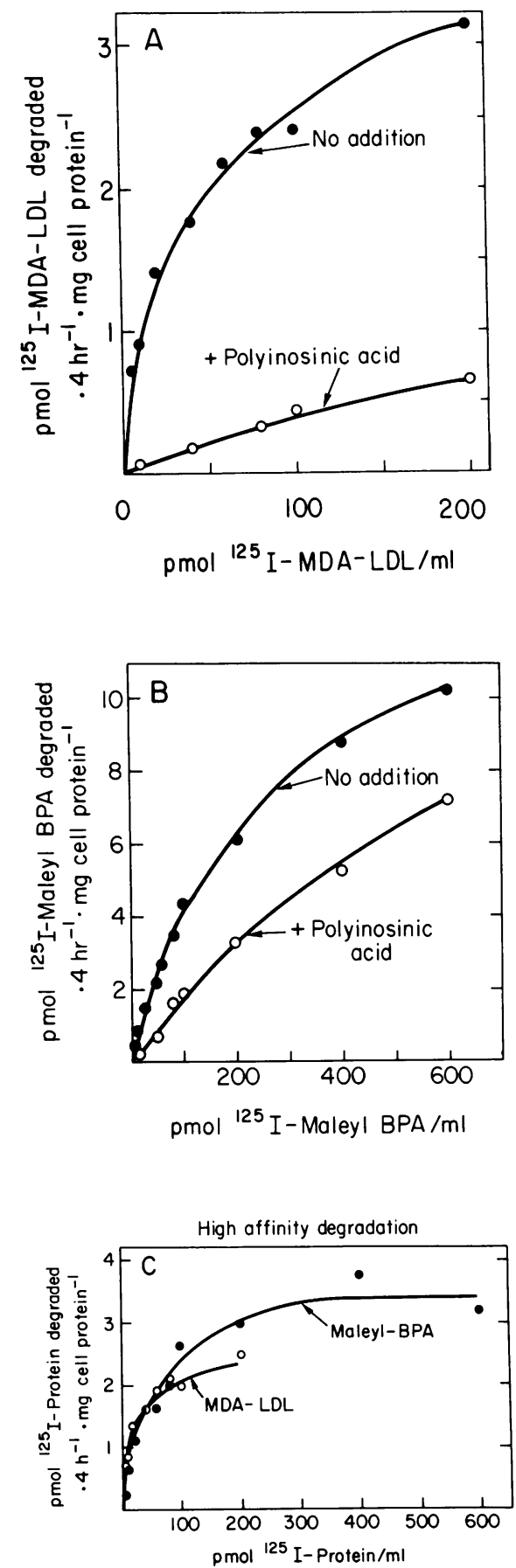

Figure 1. Comparison of the rates of degradation of MDA-LDL and maleyl-BPA as a function of protein concentration in human monocyte macrophages. Normal human monocytes were cultured in $30 \%$ autologous serum in $0.5 \mathrm{ml}$ of medium $\mathrm{B}$ for $8 \mathrm{~d}$ and were prepared for studies at $37^{\circ} \mathrm{C}$ as described in Methods. Each well received $0.5 \mathrm{ml}$ of medium $\mathrm{D}$ containing the indicated concentration of $(A) \mathrm{MDA}$ LDL $(74,700 \mathrm{cpm} / \mathrm{pmol})$ or $(B)$ maleyl-BPA $(21,300 \mathrm{cpm} / \mathrm{pmol})$ in the absence (๑) or presence (O) of $30 \mu \mathrm{g} / \mathrm{ml}$ of polyinosinic acid. After incubation for $4 \mathrm{~h}$ at $37^{\circ} \mathrm{C}$, the medium was removed and the content of ${ }^{125}$ I-labeled acid-soluble material was determined. The values shown are the mean of triplicate determinations. $C$ depicts those rates of degradation of MDA-LDL and maleyl BPA specifically suppressed by polyinosinic acid. The rates of degradation of MDA-LDL (O) or of maleyl BPA ( $\bullet$ ) were calculated from the data shown in $A$ and $B$, respectively, as the difference in rates of hydrolysis in the absence and presence of polyinosinic acid at each protein concentration. 


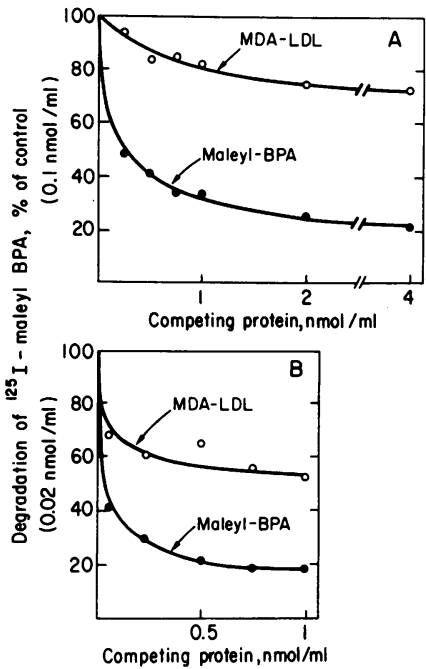

Figure 2. Competitive inhibition of the degradation of maleyl-BPA by nonradioactive MDA-LDL or maleyl-BPA. Normal human monocytes were cultured in $30 \%$ autologous serum in $0.5 \mathrm{ml}$ of medium $B$ for $8 \mathrm{~d}$ and were prepared for studies at $37^{\circ} \mathrm{C}$ as described in Methods. Each well received $0.5 \mathrm{ml}$ of medium $D$ containing $(A) 0.1 \mathrm{nmol} / \mathrm{ml}$ of maleyl-BPA $(21,300 \mathrm{cpm} /$ pmol), or $(B) 0.02 \mathrm{nmol}$ of maleyl-BPA, and the indicated concentrations of nonradioactive malondialdehyde-LDL (0) or nonradioactive maleyl-bovine plasma albumin (๑). After incubation for $4 \mathrm{~h}$ at $37^{\circ} \mathrm{C}$, the medium was removed and the content of ${ }^{125} \mathrm{I}$-labeled acid-soluble material was determined. The $100 \%$ values for the rate of degradation of maleyl-BPA in the absence of competing compounds were 3.90 and $1.48 \mathrm{pmol} / 4 \mathrm{~h}$ per $\mathrm{mg}$ cell protein for $A$ and $B$, respectively. The values shown are the mean of triplicate determinations.

partially suppressed by these same molecules, these data suggested that not only the scavenger receptor but also a second process facilitated the observed degradation of maleyl-albumin in human monocyte macrophages. To examine this possibility, the rate of degradation of maleyl-albumin as a function of protein concentration was determined in the absence or presence of selected competitive inhibitors (Fig. $4 \mathrm{~A}$ ).

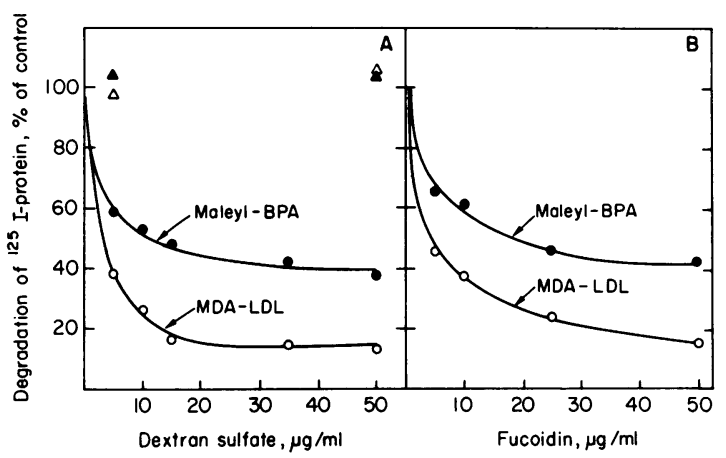

Figure 3. Effect of several competitive inhibitors of the scavenger receptor upon the degradation of maleyl-BPA and MDA-LDL. Normal human monocytes were cultured in $30 \%$ autologous serum in 0.5 $\mathrm{ml}$ of medium $\mathrm{B}$ for $9 \mathrm{~d}(A)$ or $8 \mathrm{~d}(B)$ and were prepared for studies at $37^{\circ} \mathrm{C}$ as described in Methods. In $A$, each well received $0.5 \mathrm{ml}$ of medium D containing $0.2 \mathrm{nmol} / \mathrm{ml}$ of maleyl-BPA $(0, \Delta)(18,350$ $\mathrm{cpm} / \mathrm{pmol})$ or $0.02 \mathrm{nmol} / \mathrm{ml}$ of MDA-LDL $(\bullet, \Delta)(231,700 \mathrm{cpm} /$ pmol) and the indicated concentrations of dextran sulfate either with $(\Delta, \Delta)$ or without $(\bullet, 0) 2.5 \mathrm{mM}$ spermine. In $B$, each well received 0.5 $\mathrm{ml}$ of medium D containing $0.2 \mathrm{nmol} / \mathrm{ml}$ of maleyl-BPA $(\bullet)(19,900$ $\mathrm{cpm} / \mathrm{pmol}$ ) or $0.02 \mathrm{nmol} / \mathrm{ml}$ of MDA-LDL (O) $(257,000 \mathrm{cpm} / \mathrm{pmol})$, and the indicated concentrations of fucoidin. After incubation for $4 \mathrm{~h}$ at $37^{\circ} \mathrm{C}$, the medium was removed and the content of ${ }^{125} \mathrm{I}$-labeled material was determined. The $100 \%$ values for the rates of degradation of maleyl-BPA in the absence of competing compounds were 5.53 and $6.92 \mathrm{pmol} / 4 \mathrm{~h}$ per $\mathrm{mg}$ cell protein, and of MDA-LDL, 1.61 and 3.86 $\mathrm{pmol} / 4 \mathrm{~h}$ per mg cell protein for $A$ and $B$, respectively. The values shown are the means of quadruplicate determinations.

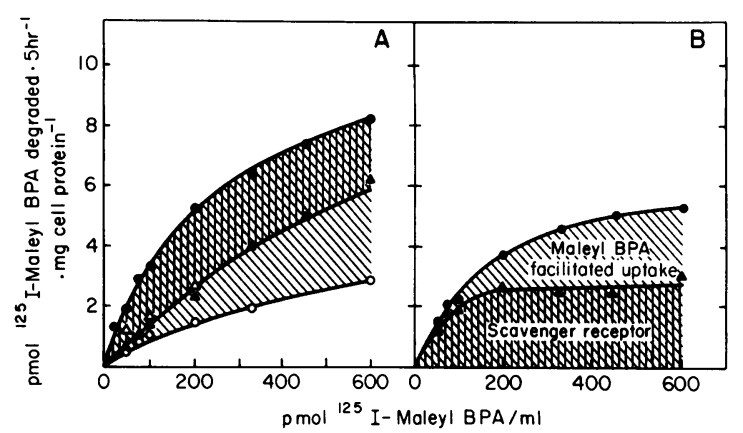

Figure 4. Rates of degradation of maleyl BPA in the absence or presence of several inhibitors $(A)$ and the specific degradation of maleylBPA in human monocyte macrophages mediated by two high affinity processes $(B)$. The same cells described in the legend to Fig. 1 were prepared for studies at $37^{\circ} \mathrm{C}$ as described in Methods. $(A)$ Each well received $0.5 \mathrm{ml}$ of medium $\mathrm{D}$ containing the indicated concentration of maleyl-BPA $(21,300 \mathrm{cpm} / \mathrm{pmol})$ in the absence $(\bullet)$ or presence of $30 \mu \mathrm{g} / \mathrm{ml}$ of polyinosinic acid ( $\triangle$ ), or a 26 -fold molar excess of nonradioactive malondialdehyde-LDL $(\Delta)$ or of nonradioactive maleyl-bovine plasma albumin (o). After incubation for $4 \mathrm{~h}$ at $37^{\circ} \mathrm{C}$, the medium was removed and the content of ${ }^{125}$ I-labeled acid-soluble material was determined. The values shown are the mean of triplicate determinations. $(B)$ The rates of degradation of maleyl-BPA calculated from the data shown in $A$ as the difference in the rates of hydrolysis in the absence and presence of polyinosinic acid or MDA-LDL ( $\Delta)$, are designated by the cross-hatched area and defined as scavenger receptor-dependent uptake. The rates of hydrolysis of maleyl-BPA, calculated as the difference in the rates of degradation in the absence and presence of nonradioactive maleyl-bovine plasma albumin (๑), are designated by the striped area; the rate of hydrolysis of maleyl-BPA determined in this manner which exceeds the scavenger receptor-dependent degradation is designated as the facilitated uptake of maleylBPA.

As expected, the addition of either malondialdehyde-LDL or polyinosinic acid suppressed the degradation of ${ }^{125} \mathrm{I}$-maleylalbumin to the same degree. Thus the use of either of these macromolecules provided a measure of the hydrolysis of ${ }^{125} \mathrm{I}$ maleyl-albumin that was due to uptake mediated by the scavenger receptor in human monocyte macrophages. The high affinity degradation of ${ }^{125} \mathrm{I}$-maleyl-albumin mediated by internalization via the scavenger receptor is shown by the cross-hatched area in Fig. $4 \mathrm{~B}$. The ability of nonradioactive maleyl-albumin to suppress the hydrolysis of ${ }^{125} \mathrm{I}$-maleyl-albumin to a greater degree than malondialdehyde-LDL (Fig. 2) was also confirmed (Fig. $4 \mathrm{~A}$ ). Based upon the inhibition by nonradioactive maleylalbumin, a saturating rate of hydrolysis of ${ }^{125} \mathrm{I}$-maleyl-albumin could be generated (Fig. $4 \mathrm{~B}$ ). This hydrolysis of ${ }^{125} \mathrm{I}$-maleylalbumin could be attributed to two processes (Fig. $4 \mathrm{~B}$ ): the uptake of ligand by the scavenger receptor (cross-hatched area) and by a second, lower affinity process (striped area). The concentration of ${ }^{125} \mathrm{I}$-maleyl-albumin necessary to saturate the scavenger receptor was $\sim 100 \mathrm{nM}(7 \mu \mathrm{g} / \mathrm{ml})$, whereas a higher concentration of ${ }^{125} \mathrm{I}$-maleyl-albumin was required to saturate the second component of facilitated uptake. Subsequent studies with three additional preparations of maleyl-bovine plasma albumin, human LDL preparations, and human monocyte macrophages obtained from different normal human subjects have confirmed the validity of the preceding data.

Maleyl-albumin of human, rabbit, and porcine origin were as effective on a molar basis as maleyl-bovine plasma albumin in suppressing the hydrolysis of ${ }^{125} \mathrm{I}$-maleyl-bovine plasma al- 
bumin (data not shown). We have previously demonstrated that maleyl-albumin after demaleylation retains the ability to compete with the hydrolysis of ${ }^{125} \mathrm{I}$-maleyl-albumin (18). Molecules that proved ineffective in suppressing the hydrolysis of either ${ }^{125} \mathrm{I}$ maleyl-albumin or ${ }^{125}$ I-MDA-LDL included lysinoalanine $\left(10^{-4}\right.$ $\left.10^{-8} \mathrm{M}\right), N$-formyl-methionyl-leucyl-phenyalanine $\left(10^{-4}-10^{-10}\right.$ $\mathrm{M})$, human LDL, rabbit $\beta$-migrating very low density lipoprotein, and acetyl-, malondialdehyde-, reductively methylated-, or native human serum albumin (data not shown).

A search for molecules specifically preventing the hydrolysis of maleyl-albumin mediated by the lower affinity, facilitated uptake component was then initiated. Bovine $\alpha$-casein proved to be an effective inhibitor. Casein itself was a poor competitor of the interaction of ligand with the scavenger receptor, based upon its inability to suppress the hydrolysis of ${ }^{125} \mathrm{I}-\mathrm{MDA}-\mathrm{LDL}$ (Fig. 5 $A$ ). As shown in Fig. $5 \mathrm{~B}$, the hydrolysis of ${ }^{125} \mathrm{I}$-maleyl-albumin mediated by both the scavenger receptor and the facilitated uptake process was suppressed $50 \%$ by casein. MalondialdehydeLDL and polyinosinic acid each produced a greater degree of suppression, 60 and $70 \%$, respectively. To examine the ability of casein to prevent the hydrolysis of ${ }^{125} \mathrm{I}$-maleyl-albumin mediated only by the facilitated uptake process, polyinosinic acid was included to inhibit recognition of maleyl-albumin by the scavenger receptor. Under these conditions, casein competed on an equimolar basis with maleyl-albumin (Fig. $5 C$ ). Results similar to those with casein have been obtained with alkaline-treated albumin (data not shown).

Such competitive assays proved useful in determining that the recognition of maleyl-albumin and malondialdehyde-LDL by human monocyte macrophages differed. It was clear, however, that more definitive evidence than patterns of partial suppression of the hydrolysis of ${ }^{125} \mathrm{I}$-maleyl-albumin would be required in

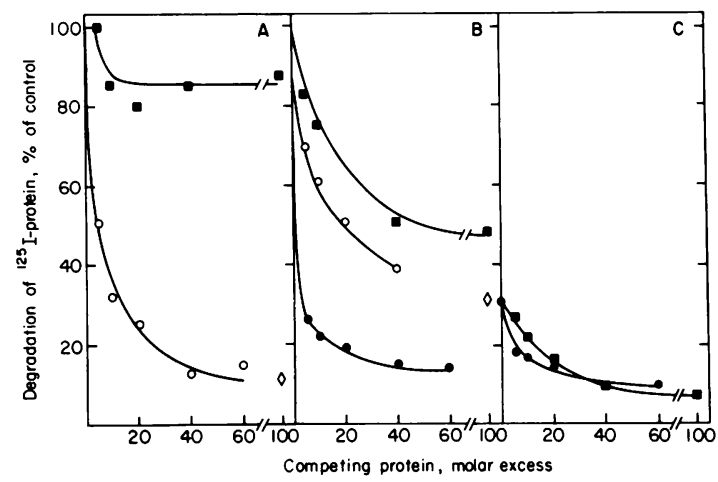

Figure 5. Effect of casein upon the degradation of maleyl-BPA and MDA-LDL. Normal human monocytes were cultured in $30 \%$ autologous serum in $0.5 \mathrm{ml}$ of medium B for $9 \mathrm{~d}$ and were prepared for studies at $37^{\circ} \mathrm{C}$ as described in Methods. Each well received $0.5 \mathrm{ml}$ of medium D containing $0.02 \mathrm{nmol} / \mathrm{ml}$ of MDA-LDL $(166,100 \mathrm{cpm} /$ $\mathrm{pmol})(A)$ or $0.15 \mathrm{nmol} / \mathrm{ml}$ of maleyl-BPA $(21,620 \mathrm{cpm} / \mathrm{pmol})$ either in the absence $(B)$ or presence $(C)$ of $100 \mu \mathrm{g}$ polyinosinic acid/ml, and the indicated concentrations of nonradioactive malondialdehyde-LDL (0), maleyl-bovine plasma albumin ( $\bullet$ ), bovine $\alpha$-casein ( $(\bullet)$, and in $A$ and $B, 100 \mu \mathrm{g}$ polyinosinic acid/ml $(\diamond)$. After incubation for $4 \mathrm{~h}$ at $37^{\circ} \mathrm{C}$, the medium was removed and the content of ${ }^{125} \mathrm{I}$-labeled material was determined. The $100 \%$ values for the rate of degradation in the absence of competing molecules of maleyl-BPA was $9.07 \mathrm{pmol} / 4 \mathrm{~h}$ per mg cell protein $(B$ and $C$ ) and of MDA-LDL, $3.87 \mathrm{pmol} / 4 \mathrm{~h}$ per mg cell protein $(A)$. The values shown are the mean of quadruplicate determinations. order to elucidate the nature of this difference in recognition. To address this issue, the specific hydrolytic rates of ${ }^{125}$ I-maleylalbumin and MDA-LDL were determined in human monocytes as a function of time in culture (Fig. 6). As we have previously demonstrated (19), the activity of the scavenger receptor, determined by the hydrolytic rate of MDA-LDL, increased with the differentiation of the monocytes into macrophages in vitro (Fig. $6, A$ and $C$ ). The specific hydrolysis of ${ }^{125} \mathrm{I}$-maleyl-albumin, however, was highest in the freshly isolated monocyte and dramatically exceeded that of MDA-LDL. The ability of the cells to degrade ${ }^{125}$ I-maleyl-albumin rapidly declined within 72 to 96 $\mathrm{h}$ after plating the cells in plastic wells. At day 7, while only 5$10 \%$ of the original specific hydrolysis of ${ }^{125} \mathrm{I}$-maleyl-albumin remained, the rate of hydrolysis of ${ }^{125} \mathrm{I}$-maleyl-albumin ap-
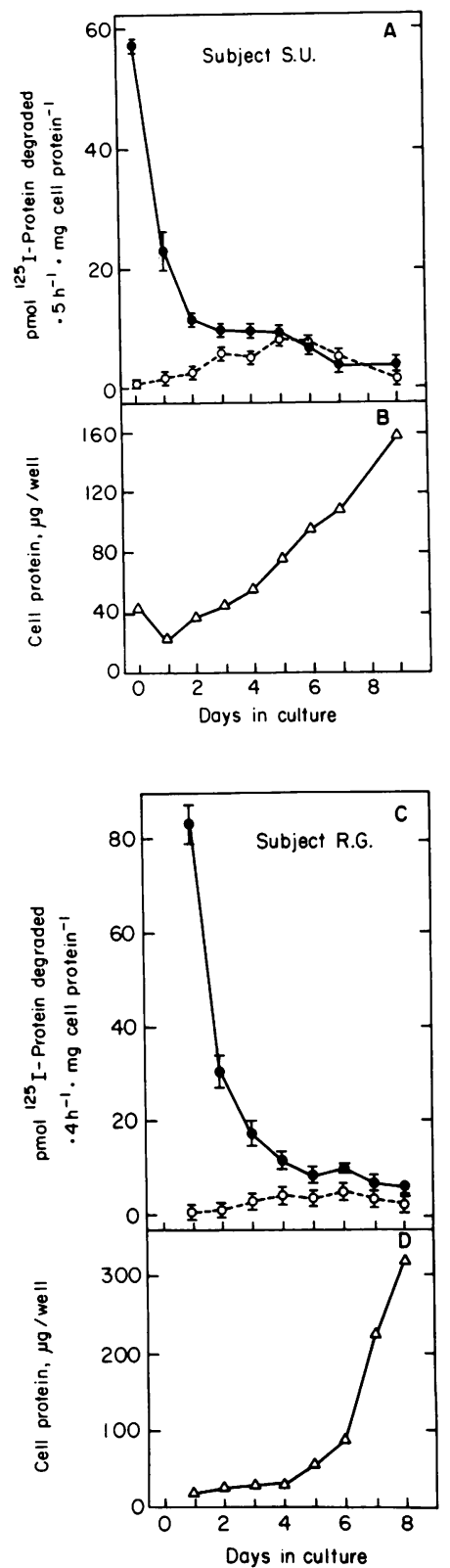

Figure 6. Specific degradation of maleyl-BPA and MDA-LDL in human monocytes as a function of time in culture. The results obtained from cells isolated from two different subjects are presented in $A$ and $B$ (subject S.U.) and $C$ and $D$ (subject R.G.), respectively. Normal human monocytes were either placed in siliconized glass tubes in medium $\mathrm{D}$ (day 0 ) or were cultured in $30 \%$ autologous serum in $0.5 \mathrm{ml}$ of medium $B$ for the times indicated and prepared for studies at $37^{\circ} \mathrm{C}$ as indicated in Methods. Cells $\left(2 \times 10^{6}\right)$ in tubes received $2.5 \mathrm{ml}$ (day 0 ) and cells $\left(0.6 \times 10^{6}\right)$ in wells received $0.5 \mathrm{ml}$ (day 1 and thereafter) of medium $D$ containing $0.2 \mathrm{nmol} / \mathrm{ml}$ of maleyl-BPA (๑) $(35,900$ $\mathrm{cpm} / \mathrm{pmol}$ ) in the absence or presence of 50-fold molar excess of nonradioactive maleyl-bovine plasma albu$\mathrm{min}$, or $0.03 \mathrm{nmol} / \mathrm{ml}$ of MDA-LDL (o) $(160,500$ $\mathrm{cpm} / \mathrm{pmol}$ ) in the absence or presence of $100 \mu \mathrm{g}$ polyinosinic acid/ml. After incubation for the time indicated at $37^{\circ} \mathrm{C}$, the medium was removed and the content of ${ }^{125}$ I-labeled acid-soluble material was determined. In $A$ and $C$ the values shown are the specific hydrolysis of each ligand, determined as the difference in degradation obtained in the absence or presence of the competitive inhibitor and represent $>85 \%$ of the total rate of degradation. In $B$ and $D$ the cell protein content was determined as described in Methods in separate tubes or wells and expressed per $0.6 \times$ $10^{6}$ monocytes initially present. 
proached that of ${ }^{125} \mathrm{I}-\mathrm{MDA}-\mathrm{LDL}$. This comparison becomes more evident in Fig. 7, in which the ratio of specific hydrolysis of the two ligands is presented as a function of time in culture. The most striking feature is that the specific degradation of maleyl-albumin exceeded that of MDA-LDL by more than two orders of magnitude in the freshly isolated monocyte. Thus, the facilitated uptake of maleyl-albumin noted in the more mature monocyte-macrophages (Fig. 4) appeared in fact to be a process that was most active in the freshly isolated cell.

Several experiments were conducted to determine if extracellular or intracellular processing accounted for the observed hydrolysis of maleyl-albumin. Chloroquine (75 $\mu \mathrm{M})$, an inhibitor of lysosomal function (37), inhibited the degradation of ${ }^{125} \mathrm{I}$ maleyl-albumin $(0.2$ and $2.9 \mathrm{nmol} / \mathrm{ml})$ and produced a linear increase in cellular associated radioactivity as a function of time $(0.5,1,1.5,2,3$, and $4 \mathrm{~h})$ in both day 1 and day 8 cells (data not shown). In separate experiments, freshly isolated monocytes or cells maintained for $7 \mathrm{~d}$ in culture were co-incubated with maleyl-albumin $(0.2$ and $2.9 \mathrm{nmol} / \mathrm{ml})$, fucoidin $(100 \mu \mathrm{g} / \mathrm{ml})$, polyinosinic acid $(100 \mu \mathrm{g} / \mathrm{ml})$, malondialdehyde-LDL $(0.06$ $\mathrm{nmol} / \mathrm{ml}$ ), or no other addition in medium D containing $0.1 \%$ human serum albumin for $48 \mathrm{~h}$. The supernatants were then examined for evidence of extracellular neutral protease activity by hydrolysis of ${ }^{125}$ I-casein as described by Johnson et al. (15). No evidence of hydrolysis was detected. Supernatants obtained after preincubation $(4 \mathrm{~h})$ with nonradioactive maleyl-albumin $(0.2 \mathrm{nmol} / \mathrm{ml})$ in cells maintained $9 \mathrm{~d}$ in culture and then coincubated with ${ }^{125}$ I-maleyl-albumin for an additional 2 or $4 \mathrm{~h}$ likewise failed to produce hydrolysis of the radioiodinated protein. Taken together, these results provide evidence that the observed degradation of ${ }^{125} \mathrm{I}$-maleyl-albumin is the result of intracellular, lysosomal processing after internalization of ${ }^{125} \mathrm{I}$-maleylalbumin.

The binding of ${ }^{125} \mathrm{I}$-maleyl-albumin as a function of concentration to freshly isolated monocytes provided evidence of a cellular surface binding site for maleyl-albumin (Fig. 8). The observed binding pattern was characteristic of a high affinity, saturable process. Maximal binding occurred at $\sim 7-10 \mu \mathrm{M}$ maleyl-albumin, a concentration far greater than required for saturation of the scavenger receptor by either malondialdehyde-

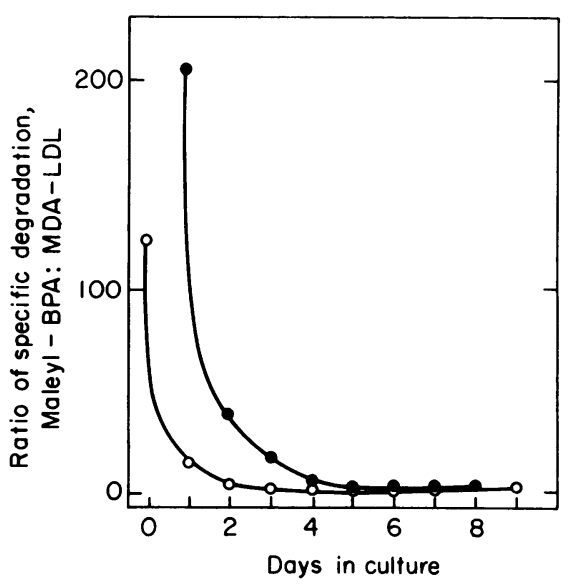

Figure 7. Ratio of the specific degradation of maleyl-bovine plasma albumin to malondialdehyde-LDL by human monocytes as a function of time in culture. Ratios were calculated from data obtained in cells from subject S.U. (O) and subject R.G. (•), $A$ and $C$ of Fig. 6, respectively.

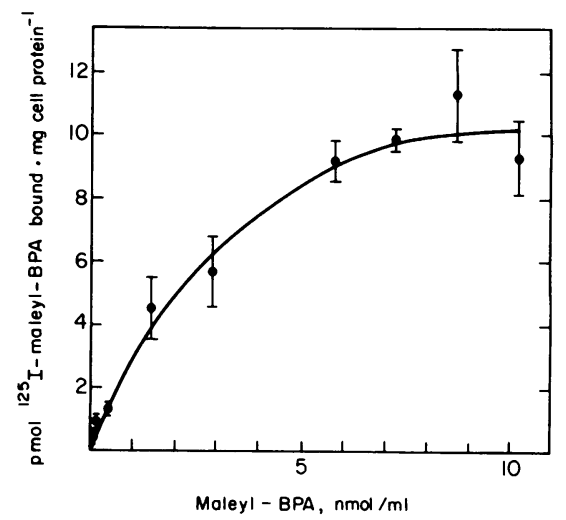

Figure 8. Binding of maleyl-BPA to freshly isolated human monocytes. Human monocytes ( $90 \%$ purity) were isolated as described in Methods and resuspended in medium $C$ containing $0.5 \%$ bovine serum albumin. Equal aliquots $(0.625 \mathrm{ml})$ of the cell preparation and maleyl-BPA $(34,815 \mathrm{cpm} / \mathrm{pmol})$ were mixed at $4^{\circ} \mathrm{C}$ in siliconized glass tubes to give a final density of $4 \times 10^{6}$ monocytes $/ \mathrm{ml}$ with the indicated concentrations of maleyl-BPA in medium $\mathrm{C}$ containing $0.5 \%$ bovine serum albumin. After gentle rotation for $2 \mathrm{~h}$ at $4^{\circ} \mathrm{C}$, aliquots $(0.25 \mathrm{ml})$ were removed and the ${ }^{125} \mathrm{I}$-protein bound per milligram cell protein determined after centrifugation of the cells through oil as described by Van Lenten et al. (36). The values shown are the mean \pm SD for quadruplicate determinations.

LDL (30 $\mathrm{nM})$ or maleyl-albumin $(100 \mathrm{nM})$ in the more mature macrophages (Fig. 1C).

The results of Fig. 7 indicated that the scavenger receptor accounted for only a small proportion of the specific hydrolysis of maleyl-albumin in monocytes as well as in cells placed in culture for $24 \mathrm{~h}$. Cellular binding assays initiated $18 \mathrm{~h}$ after isolation and culture of the monocytes confirmed that a cellular surface binding site distinct from the scavenger receptor accounted for the interaction of ${ }^{125} \mathrm{I}$-maleyl-albumin with the monocytes (Fig. 9). ${ }^{125}$ I-maleyl-albumin specifically bound to the cells substantially exceeded that of MDA-LDL. Of the total amount of maleyl-albumin bound at initial concentrations of either 0.12 or $1.6 \mu \mathrm{M}^{125} \mathrm{I}$-maleyl-albumin, the majority could be attributed to binding occurring independently of the scavenger receptor. That nonradioactive malondialdehyde-LDL failed to suppress the binding of ${ }^{125}$ I-maleyl-albumin (Fig. 9, $A$ and $B$ ) provided evidence for a binding site for maleyl-albumin separate and distinct from the scavenger receptor. Casein was as effective as maleyl-albumin in preventing the binding of ${ }^{125} \mathrm{I}$-maleyl-albumin to monocytes (Fig. 9, $A$ and $B$ ), and failed to inhibit the interaction of MDA-LDL with the human monocyte (Fig. $5 \mathrm{~A}$; Fig. 9 C).

\section{Discussion}

These data provide evidence that maleyl-albumin interacts with human blood monocytes by a second process that is separate and distinct from the well-characterized scavenger receptor pathway. The saturable binding of maleyl-albumin to freshly isolated monocytes and the internalization and lysosomal hydrolysis of maleyl-albumin are characteristic of a receptor-mediated process.

Maleyl-albumin is also recognized by the scavenger receptor of macrophages, as first described by Goldstein et al. (12) in studies with murine peritoneal macrophages. While the scavenger 


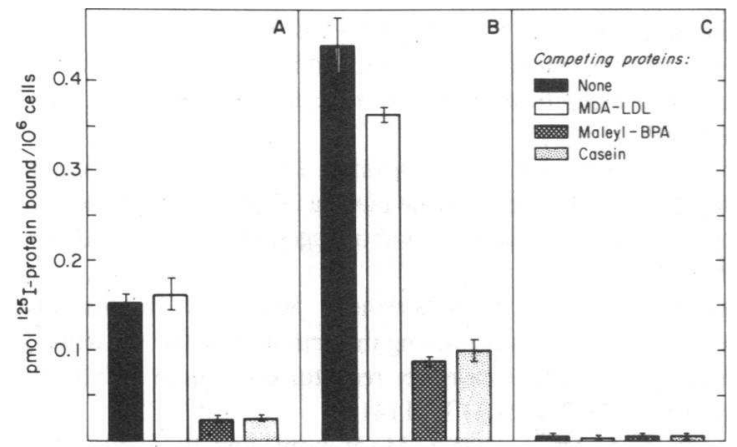

Figure 9. Effect of added competitors upon the binding of maleyl-BPA and MDA-LDL to human monocytes. Normal human monocytes were cultured in $30 \%$ autologous serum in $0.5 \mathrm{ml}$ of medium B for 18 $\mathrm{h}$ and were prepared for studies at $4^{\circ} \mathrm{C}$ as described in Methods. Each well was preincubated for $1 \mathrm{~h}$ at $4^{\circ} \mathrm{C}$ with $0.5 \mathrm{ml}$ of medium $\mathrm{C}$ containing $0.5 \%$ bovine serum albumin. The media were removed and 0.5 $\mathrm{ml}$ of medium $\mathrm{C}$ containing $0.5 \%$ bovine serum albumin together with $0.12 \mathrm{nmol} / \mathrm{ml}(A)$ or $1.6 \mathrm{nmol} / \mathrm{ml}(B)$ of maleyl-BPA $(44,537 \mathrm{cpm} /$ $\mathrm{pmol})$ or $0.026 \mathrm{nmol} / \mathrm{ml}(C)$ of MDA-LDL $(352,300 \mathrm{cpm} / \mathrm{pmol})$ in the absence (solid bars) or presence of nonradioactive MDA-LDL (open bars), nonradioactive maleyl-BPA (crosshatched bars), or nonradioactive casein (stippled bars) was added. The nonradioactive proteins were added at a 20-fold molar excess above the radioiodinated ligand. After gentle rotation for $3 \mathrm{~h}$ at $4^{\circ} \mathrm{C}$, the medium was removed and the ${ }^{125} \mathrm{I}$-protein bound per $10^{6}$ cells was determined as described in Methods. The values shown are the mean \pm SD for quadruplicate wells.

receptor is present in the freshly isolated human monocyte, maximal expression of the scavenger receptor activity occurs after a week in culture (19) and appears related to the maturation of monocytes into macrophages. Consequently, recognition of maleyl-albumin in the human cells is mediated by two separate and distinct receptors: the maleyl-albumin receptor, which is maximally expressed in freshly isolated monocytes, and the scavenger receptor, which is maximally expressed in the more mature monocyte macrophages.

Whereas maleyl-albumin serves as a probe of both receptors, malondialdehyde- $\mathrm{LDL}$ is specifically recognized by the scavenger receptor of human monocyte macrophages $(16,19,38)$ as well as of murine peritoneal macrophages (14). This differential recognition has allowed us to determine the differential expression of the activity of each receptor. That the maleyl-albumin receptor is distinct from the scavenger receptor is supported by the following evidence: ( $a$ ) malondialdehyde-LDL fails to suppress the cellular surface binding of maleyl-albumin in monocytes, while nonradioactive maleyl-albumin is an effective inhibitor (Fig. 9); (b) both the specific binding and specific hydrolysis of maleylalbumin substantially exceed those of malondialdehyde-LDL in monocytes (Figs. 6, 7, and 9); (c) the activity of the maleylalbumin receptor is highest in freshly isolated monocytes and declines rapidly over a 72-96-h period as the cells differentiate in vitro into macrophages, while the activity of the scavenger receptor is maximally expressed only after maturation of the monocytes into macrophages (Fig. 6); and (d) $\alpha$-casein and alkaline-treated albumin are effective and specific inhibitors of the interaction of maleyl-albumin with the maleyl-albumin receptor and fail to compete with the interaction of malondialdehydeLDL with the scavenger receptor (Figs. 5 and 9).

The differentiation of normal human monocytes into mac- rophages in vitro is accompanied by an immediate and rapid reduction in the activity of the maleyl-albumin receptor. It is noteworthy that, as observed by Nakagawara et al. (39), losses of monocyte functions stand in sharp contrast to increases in cell size, lysosomal hydrolase and ectoenzyme activity, and expression of cell surface receptors typically associated with the differentiation of monocytes to macrophages in vitro (40-44). Nakagawara et al. (39) have previously demonstrated that the capacity of human monocytes to produce the reactive oxygen intermediates, hydrogen peroxide and superoxide, increased $40 \%$ within $3 \mathrm{~d}$ of culture of the monocytes and rapidly fell thereafter. Of the several peroxidative enzymes investigated, only the specific activity of intracellular myeloperoxidase spontaneously and immediately declined within $4 \mathrm{~d}$ of culture to levels that were $9 \%$ of those in the freshly isolated cell. While the marked reduction in activities of myeloperoxidase and the maleyl-albumin receptor are likely to be coincidental events, each may serve as a useful index of the differentiation of human monocytes into macrophages in vitro.

Whether or not the maleyl-albumin receptor is present in murine peritoneal macrophages is difficult to assess. Maleyl-albumin has proven to be a useful probe of cellular events in murine peritoneal macrophages elicited with either thioglycollate or bacillus Calmett-Guerin $(15,45)$. Investigations conducted by Johnson et al. (15) demonstrated that addition of maleylalbumin to bacillus Calmett-Guerin-primed cells produced secretion of neutral proteases, plasminogen activator, and cytolytic factor. These responses required a minimal concentration of $730 \mathrm{nM}$ maleyl-albumin for initiation, and the levels of secretion progressively increased as a function of added maleyl-albumin up to the highest concentfation tested, $2.2 \mu \mathrm{M}$ maleyl-albumin. Induction of tumoricidal activity could also be produced in these cells by fucoidin (15), a competitive inhibitor of the scavenger receptor (14). The concentrations of maleyl-albumin necessary to induce these cellular events exceed the dissociation constants calculated to be $26 \mathrm{nM}$ for the binding of acetyl-LDL to the scavenger receptor of murine $\mathrm{P}_{388 \mathrm{D}_{1}}$ macrophages (13) and to be $270 \mathrm{nM}$ for the binding of maleyl-albumin to activated or primed murine peritoneal macrophages (45). The species origin of the cells as well as the states of differentiation and activation are sufficiently different between the preceding studies conducted with murine peritoneal macrophages $(15,45)$ and our current investigations in human monocytes that useful comparisons would require further investigation.

In light of our findings, it is of considerable interest that several investigators have demonstrated that casein- and alkalinetreated albumin induce chemotaxis in monocytes and neutrophils obtained from the human, rabbit, and guinea pig $(46,47)$. The ability of maleyl-albumin to promote chemotaxis in human monocytes is currently under investigation.

Based on the data presented here, we suggest that while maleyl-albumin provides a useful adjunct to investigation of cellular events mediated by the scavenger receptor, the occurrence of a second binding site promoting the internalization and hydrolysis of maleyl-albumin must be taken into account as a potential contributing and complicating event. Furthermore, the presence of this exceptionally active receptor-mediated process on freshly isolated monocytes suggests that it may participate in events necessary to the function of the circulating cell that diminish in importance after differentiation of the monocyte to the macrophage in vitro. Progress in addressing these and other questions will be greatly facilitated by identification of the cellular func- 
tion(s) and/or physiological ligand(s) of the maleyl-albumin receptor.

\section{Acknowledgments}

We thank Drs. Peter Edwards and Marcus Horwitz for stimulating discussions, Faranak Elahi, Kenneth Ho, Joan Burns, and Erin Burnham for excellent technical assistance, and Susan Murphy and Bonnie Streeter for secretarial support.

This study was supported in part by U. S. Public Health Service grants HL30568 and RR865, a grant from the American Heart Association, greater Los Angeles affiliate (649P5), the Laubisch Fund, and the M. K. Grey Fund.

\section{References}

1. Schaffner, T., K. Taylor, E. J. Bartucci, K. Fischer-Dzoga, J. H. Beeson, S. Glagow, and R. W. Wissler. 1980. Arterial foam cells with distinctive immunomorphologic and histochemical features of macrophages. Am. J. Pathol. 100:57-80.

2. Fowler, S., H. Shio, and N. J. Haley. 1979. Characterization of lipid-laden aortic cells from cholesterol-fed rabbits. IV. Investigation of macrophage-like properties of aortic cell populations. Lab. Invest. 41: 372-378.

3. Gerrity, R. G., H. K. Naito, M. Richardson, and C. J. Schwartz. 1979. Dietary induced atherogenesis in swine; morphology of the intima in prelesion stages. Am. J. Pathol. 95:775-792.

4. Gerrity, R. G. 1981. The role of the monocyte in atherogenesis. I. Transition of blood-borne monocytes into foam cells in fatty lesions. Am. J. Pathol. 103:181-190.

5. Gerrity, R. G. 1982. The role of the monocyte in atherogenesis II. Migration of foam cells from atherosclerotic lesions. Am. J. Pathol. 103:191-200.

6. Ross, R. 1981. Atherosclerosis: a problem of the biology of arterial wall cells and their interactions with blood components. Arteriosclerosis. 1:293-311.

7. Buja, L. M., P. T. Kovanen, and D. W. Bilheimer. 1979. Cellular pathology of homozygous familial hypercholesterolemia. Am. J. Pathol. 97:327-358.

8. Faggiotto, A., R. Ross, and L. Harker. 1984. Studies of hypercholesterolemia in the nonhuman primate. I. Changes that lead to fatty streak formation. Arteriosclerosis. 4:323-340.

9. Faggiotto, A., and R. Ross. 1984. Studies of hypercholesterolemia in the nonhuman primate. II. Fatty streak conversion to fibrous plaque. Arteriosclerosis. 4:341-366.

10. Mahley, R. W. 1979. Dietary fat, cholesterol, and accelerated atherosclerosis. Atheroscler. Rev. 5:1-34.

11. Brown, M. S., and J. L. Goldstein. 1983. Lipoprotein metabolism in the macrophage: implications for cholesterol deposition in atherosclerosis. Annu. Rev. Biochem. 52:223-261.

12. Goldstein, J. L., Y. K. Ho, S. K. Basu, and M. S. Brown. 1979. Binding site on macrophages that mediates uptake and degradation of acetylated low density lipoprotein, producing massive cholesterol deposition. Proc. Natl. Acad. Sci. USA. 76:333-337.

13. Via, D. P., H. A. Dresel, S. L. Cheng, and A. M. Gotto, Jr. 1985. Murine macrophage tumors are a source of a 260,000-dalton acetyl-low density lipoprotein receptor. J. Biol. Chem. 260:7379-7393.

14. Brown, M. S., S. K. Basu, J. R. Falck, Y. K. Ho, and J. L. Goldstein. 1980. The scavenger cell pathway for lipoprotein degradation: specificity of the binding site that mediates the uptake of negativelycharged LDL by macrophages. J. Supramol. Struc. 13:67-81.

15. Johnson, W. J., S. V. Pizzo, M. J. Imber, and D. O. Adams. 1982. Receptors for maleylated proteins regulate secretion of neutral proteases by murine macrophages. Science (Wash. DC). 218:574-576.

16. Haberland, M. E., A. M. Fogelman, and P. A. Edwards. 1982. Specificity of receptor-mediated recognition of malondialdehyde-modified low density lipoproteins. Proc. Natl. Acad. Sci. USA. 79:1712-1716.
17. Haberland, M. E., C. L. Olch, and A. M. Fogelman. 1984. Role of lysines in mediating interaction of modified low density lipoproteins with the scavenger receptor of human monocyte macrophages. J. Biol. Chem. 259:11305-11311.

18. Haberland, M. E., and A. M. Fogelman. 1985. Scavenger receptormediated recognition of maleyl bovine plasma albumin and the demaleylated protein in human monocyte macrophages. Proc. Natl. Acad. Sci. USA. 82:2693-2967.

19. Fogelman, A. M., M. E. Haberland, J. Seager, M. Hokom, and P. A. Edwards. 1981. Factors regulating the activities of the low density lipoprotein receptor and the scavenger receptor on human monocytemacrophages. J. Lipid Res. 22:1131-1141.

20. Fogelman, A. M., J. Seager, M. Hokom, and P. A. Edwards. 1979. Separation of and cholesterol synthesis by human lymphocytes and monocytes. J. Lipid Res. 20:379-388.

21. Fogelman, A. M., J. Edmond, J. Seager, and G. Popjak. 1975. Abnormal induction of 3-hydroxy-3-methlglutaryl coenzyme A reductase in leukocytes from subjects with heterozygous familial hypercholesterolemia. J. Biol. Chem. 250:2045-2055.

22. Havel, R. J., H. A. Eder, and J. H. Bragdon. 1955. The distribution and chemical composition of ultracentrifugally separated lipoproteins of human serum. J. Clin. Invest. 43:1345-1353.

23. King, T. P., and M. Spencer. 1970. Structural studies and organic ligand-binding properties of bovine plasma albumin. J. Biol. Chem. 245: 6134-6148.

24. Butler, P. J. G., and B. S. Hartley. 1972. Maleylation of amino groups. Methods Enzymol. 25B:191-199.

25. Weisgraber, K. H., T. L. Innerarity, and R. W. Mahley. 1978. Role of the lysine residues of plasma lipoproteins in high affinity binding to cell surface receptors on human fibroblasts. J. Biol. Chem. 253:90539062.

26. Wilkinson, P. C., and R. B. Allan. 1978. Binding of protein chemotactic factors to the surfaces of neutrophil leukocytes and its modification with lipid-specific bacterial toxins. Mol. Cell. Biochem. 20:2540.

27. McFarlane, A. S. 1958. Efficient trace-labelling of proteins with iodine. Nature (Lond.). 182:53.

28. Bilheimer, D. W., S. Eisenberg, and R. I. Levy. 1972. The metabolism of very low density lipoproteins. I. Preliminary in vitro and in vivo observations. Biochim. Biophys. Acta. 260:212-221.

29. Fogelman, A. M., I. Shechter, J. Seager, M. Hokom, J. S. Child, and P. A. Edwards. 1980. Malondialdehyde alteration of low density lipoproteins leads to cholesteryl ester accumulation in human monocytemacrophages. Proc. Natl. Acad. Sci. USA. 77:2214-2218.

30. Habeeb, A. F. S. A. 1966. Determination of free amino groups in proteins by trinitrobenzenesulfonic acid. Anal. Biochem. 14:328-336.

31. Steele, J. H., Jr., and J. A. Reynolds. 1979. Molecular weight and hydrodynamic properties of apolipoprotein B in guanidine hydrochloride and sodium dodecyl sulfate solutions. J. Biol. Chem. 254:16391643.

32. Peters, T., Jr. 1975. Serum albumin. In The Plasma Proteins: Structure, Function, and Genetic Control, Vol. 1. F. W. Putnam, editor. Academic Press, Inc., New York. 133-181.

33. McKenzie, H. A. 1967. Milk proteins. Adv. Protein Chem. 22. $55-234$.

34. Lowry, O. H., M. J. Rosebrough, A. L. Farr, and R. J. Randall. 1951. Protein measurement with the Folin phenol reagent. J. Biol. Chem. 193:265-275.

35. Goldstein, J. L., and M. S. Brown. 1974. Binding and degradation of low density lipoproteins by cultured fibroblasts. J. Biol. Chem. 249: 5153-5162.

36. Van Lenten, B. J., A. M. Fogelman, R. L. Jackson, S. Shapiro, M. E. Haberland, and P. A. Edwards. 1985. Receptor-mediated uptake of remnant lipoproteins by cholesterol-loaded human monocyte-macrophages. J. Biol. Chem. 260:8783-8788.

37. Goldstein, J. L., G. Y. Brunschede, and M. S. Brown. 1975. Inhibition of the proteolytic degradation of low density lipoprotein in 
human fibroblasts by chloroquine, concanavalin A and Triton WR 1339. J. Biol. Chem. 250:7854-7862.

38. Shechter, I., A. M. Fogelman, M. E. Haberland, J. Seager, M. Hokom, and P. A. Edwards. 1981. The metabolism of native and malondialdehyde-altered low density lipoproteins by human monocytemacrophages. J. Lipid Res. 22:63-71.

39. Nakagawara, A., C. F. Nathan, and Z. A. Cohn. 1981. Hydrogen peroxide metabolism in human monocytes during differentiation in vitro. J. Clin. Invest. 68:1243-1252.

40. Cohn, Z. A., and B. Benson. 1964. The differentiation of mononuclear phagocytes. Morphology, cytochemistry, and biochemistry. $J$. Exp. Med. 121:153-170.

41. Johnson, W. B., B. Mei, and Z. A. Cohn. 1977. The separation, long-term cultivation, and maturation of the human monocyte. J. Exp. Med. 146:1613-1626.

42. Zuckerman, S. H., S. K. Ackerman, and S. D. Douglas. 1979. Long-term human peripheral blood monocyte cultures: establishment, metabolism and morphology of primary human monocyte-macrophage cell cultures. Immunology. 38:401-411.

43. Musson, R. A., H. Shafran, and P. M. Henson. 1980. Intracellular levels and stimulated release of lysosomal enzymes from human peripheral blood monocytes and monocyte-derived macrophages. J. Reticuloendothel. Soc. 23:249-264.

44. Wright, S. D., and S. C. Silverstein. 1982. Tumor-promoting phorbol esters stimulate $\mathrm{C} 3 \mathrm{~b}$ and $\mathrm{C} 3 \mathrm{~b}^{\prime}$ receptor-mediated phagocytosis in cultured human monocytes. J. Exp. Med. 156:1149-1164.

45. Imber, M. J., S. V. Pizzo, W. J. Johnson, and D. O. Adams. 1982. Selective diminution of the binding of mannose by murine macrophages in the late stages of activation. J. Biol. Chem. 257:5129-5135.

46. Wilkinson, P. C., and G. R. Bradley. 1981. Chemotactic and enzyme-releasing activity of amphipathic proteins for neutrophils. A possible role for proteases in chemotaxis on substratum-bound protein gradients. Immunology. 42:637-648.

47. Wilkinson, P. C. 1982. Chemotaxis and Inflammation. Churchill Livingstone, New York. 1-242. 